\title{
THE IMPORTANCE OF EUROPEAN FUNDING ON PUBLIC FINANCES IN ROMANIA - IMPLICATIONS FOR THE GENERAL CONSOLIDATED BUDGET OF THE STATE
}

\author{
Cristina Maria BĂTUȘARU \\ Continental Automotive Systems SRL, Sibiu, Romania \\ cristina_batusaru@yahoo.com
}

\begin{abstract}
The "health" state of the economy which will receive European funding is a key element in the efficiency with which these funds can be used, the effects that the injection of foreign capital entails are being significant at the macroeconomic level, since a Member state of the European Union eligible to receive finance capital can absorb a flow of up to 4\% of GDP. The manner of the allocation of these funds is also a key component of efficient use of European funds allocated under the multiannual financial programming period. Annual indicative allocation corresponding to the seven years of a programming period allows to identify specific priorities for investment of these funds and the co-financing obligation incumbent upon the recipient state has the role to lead to a more responsible and appropriate use of these funds. However, the gradual release of these cash flows in the national economy may lead to a delay in the occurrence of short-term positive results for the economy, given that the allocation is made after approval by the European Commission of some strategic documents that the recipient state assumes to follow according to common objectives. Beyond the effort that the recipient state must make to become eligible for European funding, the longterm effects of the injection of capital into the economy are significant and certainly favorable to the economic and social development as a whole. One of the controversial issues on the opportunity of accessing European funding is represented by the financing cost that this entails. The problematic issues that the injection of foreign capital flows have on fiscal policy and their implications on the general consolidated budget of the state are complex and are a subject of debate among researchers in economics.
\end{abstract}

\section{Keywords: national budget, finances, deficit, European funds}

\section{Introduction}

Analyzing the role and implications that the transfers coming from the European Union have on the national economy is very complex and complicated due to the multitude of issues and indicators that they shape and train, depending on the source of funding, allocation mode and the purpose for which it was allocated.

The implications of absorption of EU funds on the national budget can be addressed by defining its two components namely the revenue and the expenditure. With reference to the first component, the revenue, two aspects must be taken into considerations:

- The direct value of the attracted revenues - represents the effective amount recorded in the national budget according to the amounts received from the EU budget. This value has a "maximum threshold" represented by the indicative amount of EU funds that can be annually accessed as planned in the Multiannual Financial Framework of the corresponding programming period. 
This indicative value represents possible income to be received by the beneficiary state, but not certain, bringing into question a key element of European funding policy, namely the absorption capacity of EU funds as measured by the rate of absorption.

- The indirect value of the attracted revenues - represents money raised at the general consolidated government budget in the form of collected taxes as a result of economic activity taking place at national level and financed through the Structural Funds allocated to the implemented operational programs.

The second component of the budget system, the expenditure, brings into discussion the position of taxpayer of state, which cannot be only a net beneficiary of EU funding. Thus, costs are involved in the national budget in terms of two broad categories of contributions:

- The contribution to the EU budget which raises to about $1 \%$ of annual GDP;
- The state's contribution related to the co-financed programs by the European Union - ranging between 15-25\% depending on the financing instrument (FC, FS, ERDF etc.)

- Financing the EU Budget from EU Member States is provided through three levers, namely:

- contribution from VAT - which is set as a rate from the total base of national VAT;

- The contribution from gross national income (GNI) - the most important source for the establishment of Community budget resources, representing approximately $60 \%$ of total resources;

- Traditional own resources - represented by customs and agricultural duties, and sugar levies.

Table 1 - Romania's contribution to EU budget between 2007-2013

- Million EURO -

\begin{tabular}{|l|c|c|c|c|c|c|c|c|}
\hline \multicolumn{1}{|c|}{ Year } & $\mathbf{2 0 0 7}$ & $\mathbf{2 0 0 8}$ & $\mathbf{2 0 0 9}$ & $\mathbf{2 0 1 0}$ & $\mathbf{2 0 1 1}$ & $\mathbf{2 0 1 2}$ & $\mathbf{2 0 1 3}$ & $\mathbf{2 0 1 4}$ \\
\hline $\begin{array}{l}\text { Total } \\
\text { contributions } \\
\text { from TOR }\end{array}$ & 158,9 & 198,7 & 125,1 & 101,8 & 121 & 127,6 & 108,9 & 155,2 \\
\hline $\begin{array}{l}\text { Contributions } \\
\text { from VAT }\end{array}$ & 162,1 & 168,5 & 156,6 & 124,2 & 145,3 & 142,2 & 155,3 & 163,5 \\
\hline $\begin{array}{l}\text { GNI resource } \\
\text { contributions }\end{array}$ & 680,3 & 738,9 & 901,3 & 858,1 & 964,5 & 973,7 & 1126,4 & 1100,8 \\
\hline Corrections ** & 85,6 & 107,1 & 153,6 & 59,1 & 59,9 & 80,4 & 84,7 & 109,3 \\
\hline $\begin{array}{l}\text { Ro contribution } \\
\text { to EU budget }\end{array}$ & 1086,9 & 1213,2 & 1336,6 & 1143,2 & 1290,7 & 1323,9 & 1475,3 & 1528,8 \\
\hline $\begin{array}{l}\text { Romania's GDP } \\
\text { \% Total }\end{array}$ & 125328,2 & 142392,5 & 120483,1 & 126815,6 & 133343,7 & 133610,3 & 144253,5 & 148179,8 \\
\hline $\begin{array}{l}\text { \%ontribution to } \\
\text { GDP }\end{array}$ & $\mathbf{0 , 8 7}$ & $\mathbf{0 , 8 5}$ & $\mathbf{1 , 1}$ & $\mathbf{0 , 9}$ & $\mathbf{0 , 9 6}$ & $\mathbf{0 , 9 9}$ & $\mathbf{1 , 0 2}$ & $\mathbf{1 , 0 3}$ \\
\hline
\end{tabular}

NBR on site www.bnr.ro 
From the perspective of the beneficiary of European funds for 2007-2013, the status of payments made by the European
Commission to Romania under Net financial balance is as follows:

Table 2 - Amounts received by Romania from the EU budget during 2007-2014 - Million EUR -

\begin{tabular}{|l|c|c|c|c|c|c|c|c|}
\hline \multicolumn{1}{|c|}{ Year } & $\mathbf{2 0 0 7}$ & $\mathbf{2 0 0 8}$ & $\mathbf{2 0 0 9}$ & $\mathbf{2 0 1 0}$ & $\mathbf{2 0 1 1}$ & $\mathbf{2 0 1 2}$ & $\mathbf{2 0 1 3}$ & $\mathbf{2 0 1 4}$ \\
\hline $\begin{array}{l}\text { Amounts received from } \\
\text { EU }\end{array}$ & 790 & 1890 & 2310 & 2020 & 2490 & 3400 & 5530 & 5910 \\
\hline $\begin{array}{l}\text { \% payments by the EU to } \\
\text { Romania in GDP }\end{array}$ & 0,63 & 1,33 & 1,92 & 1,59 & 1,87 & 2,54 & 3,38 & 3,98 \\
\hline
\end{tabular}

Source: author's calculations based on data from the 2015 Budget Report

If is to compare the two perspectives of state's position in the tables nr.1-2, it can be notices that Romania was a net beneficiary in the financial relationship with the European Union, highlighting that efforts made in order to improve the absorption is essential for tracking the path implied since 2012. Thus, following the "n +2 " rule which gives Member eligible to receive European financing the opportunity of two years extension to access the funds allocated if they failed to absorb them in the programming period, Romania should have paid attention to the year 2015 which was the last year of eligibility of expenditure corresponding to the Multiannual Financial Framework for 2007-2013.

\section{Impact absorption of EU funds on the budget deficit}

Although there has been a progress from year to year, the cumulative amount of payments made by the European Commission recorded a value of about $17 \%$, but the rate of absorption of EU funds was still low since the equivalent of postaccession funds represents about 24\% of GDP. In order to establish the importance that full absorption of structural and cohesion funds has on public finances and on reducing the budget deficit, in the table below it's shown a comparative analyze between the indicator values registered by Romania in 2007-2013 on European funds absorption compared with the annual indicative value and the values that would have been obtained in case of full absorption.

Table 3 - Impact absorption of EU funds on the budget deficit (actual scenario v.s. full absorption scenario) - Milion Ron

\begin{tabular}{|c|c|c|c|c|c|c|c|}
\hline \multicolumn{7}{|c|}{ Real Scenario } \\
\hline Year & $\begin{array}{c}\text { Budgetary } \\
\text { Revenue } \\
\text { (A) }\end{array}$ & $\begin{array}{c}\text { Budgetary } \\
\text { Expenditure } \\
\text { (B) }\end{array}$ & $\begin{array}{c}\text { Budgetary } \\
\text { Deficit } \\
\text { (A-B) }\end{array}$ & GDP & $\begin{array}{c}\text { Amounts } \\
\text { received } \\
\text { from EU } \\
(\mathbf{D})\end{array}$ & $\begin{array}{c}\text { Indicative } \\
\text { allocation } \\
\text { of EU } \\
\text { Funds (C) }\end{array}$ & $\begin{array}{c}\text { Budgetary } \\
\text { Deficit } \\
\text { \% GDP }\end{array}$ \\
\hline 2007 & 48984,6 & 64373,5 & $-15388,9$ & 418257,9 & 1406,3 & 4455,3 & 3,68 \\
\hline 2008 & 61151 & 80886,4 & $-19735,4$ & 52488,9 & 2388,05 & 7052,4 & 3,76 \\
\hline 2009 & 56434,8 & 89851,7 & $-33416,9$ & 510522,8 & 4118 & 10915,3 & 6,54 \\
\hline 2010 & 66546,5 & 102627,8 & $-36081,3$ & 533881,1 & 2128,3 & 13017 & 6,76 \\
\hline 2011 & 79688 & 106088,7 & $-26400,7$ & 565097,2 & 3002 & 14112,2 & 4,67 \\
\hline 2012 & 86018,8 & 104569,8 & -18551 & 595367,3 & 5217,6 & 15952,5 & 3,12 \\
\hline 2013 & 90945,1 & 110128,1 & -19183 & 637456 & 13094 & 16955,7 & 3,01 \\
\hline
\end{tabular}




\begin{tabular}{|c|c|c|}
\hline \multicolumn{2}{|c|}{ Full Absorption Scenario } & - Million Ron- \\
\hline $\begin{array}{l}\text { Outstanding amounts } \\
\text { to be absorbed from EU } \\
\text { Funds (C-D) }\end{array}$ & $\begin{array}{l}\text { Budget deficit corrected with } \\
\text { full absorption of EU Funds }\end{array}$ & $\begin{array}{l}\text { Budgetary } \\
\text { Deficit } \\
\% \text { GDP }\end{array}$ \\
\hline 3049 & $-12339,9$ & 2,95 \\
\hline 4664,35 & $-15071,05$ & 2,87 \\
\hline 6797,3 & $-26619,6$ & 5,21 \\
\hline 10888,7 & $-25192,6$ & 4,72 \\
\hline 11110,2 & $-15290,5$ & 2,71 \\
\hline 10734,2 & $-7816,8$ & 1,31 \\
\hline 3861,7 & $-15321,3$ & 2,4 \\
\hline
\end{tabular}

Of course the two perspectives presented in Table No.3 presents a minimalist approach to the phenomenon, but suggestive enough to capture the importance of this source of financing national budget revenues and how approaching this field with full responsibility can have a key contribution on keeping within certain assumed limits one of the most important indicators against which public finance policy is founded, namely the budget deficit.

Comparing the values recorded in the budget deficit as a share of GDP in the two discussed scenarios, it appears that in the case of full absorption of allocated EU funds, this indicator has lower values, ranging from 0.73 to 2.04 compared to actual scenario. This difference is significant if we consider the commitment by signing the Treaty of Stability, Coordination and Governance in the Economic and Monetary Union, according to which the planned target for funding under the agreement concluded with the European Union and International Monetary Fund is $1.45 \%$ of GDP for 2015, a figure which includes an adjustor of 0.25 percentage points to GDP for co-financing projects supported by EU funds.

For the period from 2016-2018, the aim is to reduce the cash deficit at $1.8 \%$, which corresponds to a ESA deficit of $1.2 \%$ of GDP and a structural deficit of $1 \%$ of the GDP. Given these targets presented in the Government Program for the period 20152018, a prognosis was carried out using the
WinQSB [1] software, in order to study the evolution of the budget deficit for 20142020 in the context of a cash deficit recorded on a hypothesis of full absorption of EU funds for the period 2007-2013.

Results from statistical modeling data are presented below.

Results from statistical modeling data are presented below.

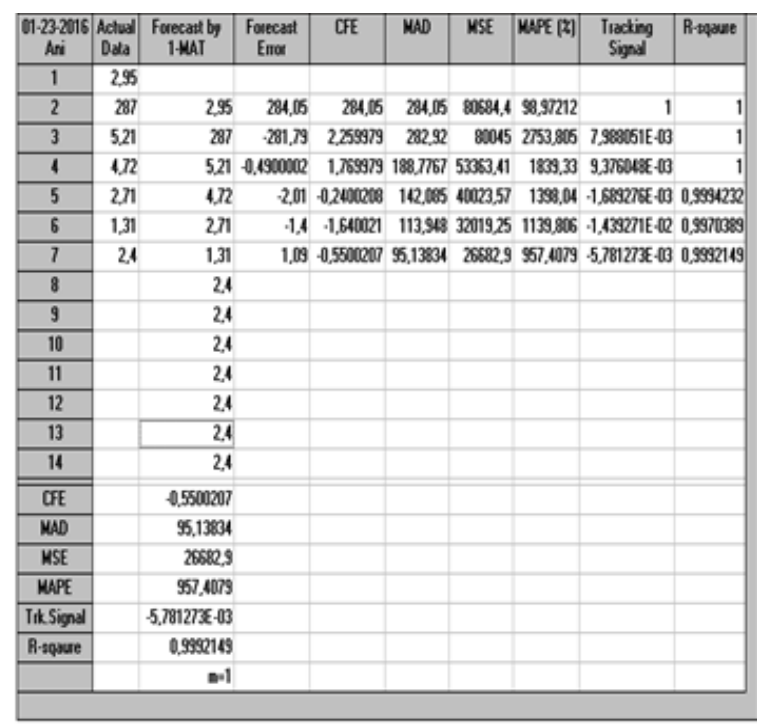

Figure 1 - forecast results for the budget deficit as a share of GDP obtained through WinQSB [1] software.

In other words, the maximum projected budget deficit as \% of GDP for the period $2015-2020$ is 2.95 and the minimum is 1.85. The minimum value obtained for the indicator studied meet budgetary policy objective set out in the Government Program under which the aim is to reduce the budget cash deficit to $1.8 \%$. This 
confirms the significant importance that EU funds have on the budgetary-fiscal policy and sounding among fiscal policy makers, and others, on the opportunities that the new wave of EU assistance programming for the period 2014-2020 brings, given that European funds are addressed as a priority in ensuring sustainable public finances in Romania.

\section{Multiannual Financial Framework for the period 2014-2020 - perspectives for Romania}

Multiannual Financial Framework (MFF) is a mechanism developed by the European Commission setting out the financial perspective intended to predict EU spending and respect for strict budgetary discipline. Under this MFF ceilings are established the funds for the Operational Programs for each EU Member State. Multiannual Financial Framework defines long-term EU priorities and sets annual maximum amounts to be spent on each priority basis. It is built over a period of seven years (2000-2006, 2007-2013 and 2014-2020) and before three years from completion of a framework it is proposed a new multiannual framework.

Full absorption of EU funds for the two multiannual financial frameworks programming periods $2007-2013$ and 20142020 should have been a top priority of the Romanian Government, as they represent a significant and valuable resource for achieving socio-economic development in the medium and long term, as they are a key element in the sustainability of public finances in terms of investment strategy and the nature of the grant funds.

Romania's experience in accessing European funds for 2007-2013 revealed a number of problems regarding Romania's administrative capacity to manage the implemented operational programs, problems that have constituted barriers to effective absorption of these funds. The absorption rate certified by the European Commission at the end of 2015 is approximately $60 \%$, which is equivalent to the loss of significant funds that Romania would be able to assert national goals and community commitments.

Concentrating its efforts in the future, Romania must take into account the provisions of the MFF 2014-2020, adopted at the end of 2013. For Romania 2007-2013 experience should contribute to an increased absorption of funds provided for the new MFF, for which Romania has been allocated more funds than in the previous multiannual financial framework (approximate 43 milliard Euro).

The total allocations for cohesion policy and the common agricultural policy which benefits Romania represents an increase of $17 \%$ compared to the total allocations for the period 2007-2013. It is one of the largest growth rates recorded among Member States for the new financial framework of cohesion policy. Also, according to the European Commission, the allocation of which Romania will benefit in the Multiannual Financial Framework 2014-2020 places our country in the first four beneficiaries of cohesion policy.

It is essential for Romania, considering the period 2007-2013 had reached about 34.6 million euros of European funds to identify those weaknesses which prevented her to record a high absorption rate of these funds and take a set of measures to streamline the process. Some of the measures that should be taken for the programming period 20142020 refer to the following aspects [2]:

- to carefully analyze the available European funding programs and identify the real development needs of the Romanian economy sectors;

- to implement the strategies at local level, meaning that county and regional authorities should establish at each administrative-territorial unit those priority projects which 
contribute to a balanced regional development;

- to create a legal framework to reduce bureaucracy, to create a clear regulation with the duties and responsibilities of each institution involved in the management and control of EU funds, the imposition of a single framework for access and reimbursement and to accelerate the process of public procurement from European funds by increasing the attention to the approach of publication of tender documentation in SEAP;

- to Strengthen the administrative capacity of the structures involved in the management of operational programs;

- to motivate the private sector to participate in projects through outsourcing or partnership arrangements between public and private sector;

- to ensure full employment staffing of project management units and adequate remuneration of the specialized staff, funded by technical assistance programme;

- appropriate training of staff involved in activities with European funds and launching programs that contribute to the training of personnel who will benefit of jobs in sectors of interest where European funds can be accessed;

- effective absorption of EU financial resources that are allocated for human resources development, so as to provide support for professional training and employment.

Romania must also take into account the co-financing of EU funded projects, a process that frees budgetary resources for utilities that are not covered from public revenues. The assumptions is that EU funds provided by the programming period 2014-
2020 will help to supplement domestic public resources in a time when deficit reduction is one of the major priorities for Romania. Accessed under optimal conditions, these funds could have a counter-cyclical function with a positive effect on budget implementation, contributing to alleviate pressure on the budget deficit that must be kept within certain limits according to the commitments assumed with the European Commission.

An argument for increasing the access to European funds could come from institutional reconstruction done at central level. The Ministry of European Funds received increased powers to the former Ministry of European Affairs (which can also control how grants are spent) and some services corresponding to management authorities were outsourced [3]. However, it should be noted that the reasons that negatively affects the process of accessing European funds are many and diverse, and in order to improve this process in Romania, some measures should be taken at the level of each body involved in the management of European funds.

\section{Conclusions}

This scientific approach of using scenarios to create a prognosis in the estimation of future direct costs charged to Romania through its EU Membership, does not aim to be a real forecast model, given the restrictions imposed by the small number of variables studied in model analysis, but its aim is to capture the sensitive interdependence between the evolution of these key indicators measuring the impact of European funding on the national budget. Individual approach to the concept of "high rate of absorption of European funds", does not guarantee economic growth, as long as the implemented projects do not serve the needs and realistic goals of a strategic socio-economic development, in order to support the national progress and Romania's 
alignment with EU standards. Romania can be considered an example of "not so" in terms of experience in implementing the operational programs under the 2007-2013 programming period, since the objectives set in the National Development Plan have not been met accordingly.

\section{References}

[1] Amelia Bucur, Contribuţii la abordarea ştiinţifică a calităţii şi managementului calităţii, prin modelare şi simulare, Publishing House of Lucian Blaga University, Sibiu, 2015, pp.83-91;

[2] Bătușaru Cristina Maria, Contribuția Finanțărilor Europene la creșterea resurselor financiare publice în România, Proceedings of $1^{\text {st }}$ International $\mathrm{PhD}$ Students Conference, Faculty of Economic Science Sibiu, Romania, 2013.

[3] Iosif Moldovan, Finanțarea proiectelor din fonduri europen, Sibiu, Publishing House of Lucian Blaga University, 2013, pp.36. 